\title{
Living (Rose-Bengal-stained) benthic foraminiferal faunas along a strong bottom-water oxygen gradient on the Indian margin (Arabian Sea)
}

\author{
C. Caulle $^{1, a}$, M. Mojtahid ${ }^{1}$, A. J. Gooday ${ }^{2}$, F. J. Jorissen ${ }^{1}$, and H. Kitazato ${ }^{3}$ \\ ${ }^{1}$ UMR CNRS6112 LPG-BIAF, Recent and Fossil Bio-Indicators, Angers University, 2 Bd Lavoisier, \\ 49045 Angers CEDEX 01, France \\ ${ }^{2}$ National Oceanographic Centre, University of Southampton Waterfront Campus, European Way, Southampton, \\ SO14 3ZH, UK \\ ${ }^{3}$ Japan Agency for Marine-Earth Science and Technology (JAMSTEC), 2-15 Natsushimacho, Yokosuka 237-0061, Japan \\ ${ }^{a}$ now at: IFREMER, Laboratoire DYNECO/PELAGOS, Centre de Brest, Technopôle de Brest-Iroise, BP 70, \\ 29280 Plouzané, France
}

Correspondence to: C. Caulle (clemence.caulle@gmail.com)

Received: 7 January 2015 - Published in Biogeosciences Discuss.: 17 February 2015

Accepted: 5 August 2015 - Published: 25 August 2015

\begin{abstract}
Rose-Bengal-stained foraminiferal assemblages $(>150 \mu \mathrm{m})$ were analysed along a five-station bathymetric transect across the core and the lower part of the oxygen minimum zone (OMZ) on the Indian margin of the Arabian Sea. Sediment cores were collected using the manned submersible Shinkai 6500 during the RV Yokosuka cruise YK08-11 in the post-monsoon season (October 2008) at water depths ranging from 535 to $2000 \mathrm{~m}$, along a gradient from almost anoxic to well-oxygenated $(0.3$ to $108 \mu \mathrm{M})$ bottom waters. Stained benthic foraminifera were investigated from two different size fractions $(150-300 \mu \mathrm{m}$ and $>300 \mu \mathrm{m})$. Stained foraminiferal densities were very high in the core of the OMZ (at 535 and $649 \mathrm{~m}$ ) and decreased at deeper sites. The faunas $(>150 \mu \mathrm{m})$ were dominated $(40-80 \%)$ by non-calcareous taxa at all stations. These were mainly species of Reophax and Lagenammina but also included delicate monothalamous taxa (organic-walled "allogromiids", agglutinated saccamminids, psammosphaerids and tubular forms). These new data from the Indian margin are compared to previous studies from the Murray Ridge, the Pakistan margin and the Oman margin. The fact that similar species were found at sites with comparable bottom-water oxygen concentrations but with very different surface water productivity suggests that, within the strongly developed Arabian Sea OMZ, bottomwater oxygen concentration, and not the organic flux to the sea floor, is the main factor controlling the species composi-
\end{abstract}

tion of the foraminiferal communities. Several foraminiferal species (e.g. Praeglobobulimina sp. 1, Ammodiscus sp. 1, Bolivina aff. dilatata) were confined to the core of the OMZ. These species are presently known only from the Arabian Sea. Because of their association with extremely low oxygen concentrations, these species may be good markers for very low oxygen concentrations, and could be used to reconstruct past OMZ variability in the Arabian Sea.

\section{Introduction}

The ocean floor hosts rich and diverse micro-, meio- and macrofaunal communities. The distribution and abundances of these faunas are controlled by many environmental and physical parameters that change from the continental shelf to the deep ocean. In particular, organic-matter fluxes and bottom-water oxygenation exhibit drastic changes between oceanic basins. Strong gradients in both parameters are found in oxygen minimum zones (OMZ; defined by permanent hypoxia, with dissolved oxygen concentrations $\langle 22 \mu \mathrm{M}$; Levin, 2003). These mid-water features impinge on the continental slope at upper bathyal depths in the eastern Pacific, the northern Indian Ocean (Arabian Sea and Bay of Bengal), and to a lesser extent off southwest Africa (Helly and Levin, 2004; 
Paulmier and Ruiz-Pino, 2009). Many studies have described dense biotic communities within OMZs, despite the low oxygen concentrations (e.g. Wishner et al., 1990; Levin et al., 1991; Jannink et al., 1998; Gooday et al., 2000, 2009; Levin et al., 2000; Levin, 2003; Schumacher et al., 2007; Mallon et al., 2012; Pozzato et al., 2013). In general, meiofaunal organisms (mainly foraminifera and nematodes) attain high densities, although diversity tends to be low (e.g. Jannink et al., 1998; Cook et al., 2004; Schumacher et al., 2007; Larkin and Gooday, 2009; Caulle et al., 2014). Megafaunal and most macrofaunal taxa are more affected by strong hypoxia than smaller organisms and usually exhibit lower abundances, except for polychaetes which are often more resistant and may be abundant, even in the core regions of some OMZs (e.g. Levin et al., 1991; Levin, 2003; Gooday et al., 2009). However, in all size classes, distinct taxonomic changes are observed across OMZs (e.g. Gooday et al., 2009), making them perfect natural laboratories to examine the influence of oxygen concentration on the density, diversity and species composition of benthic fauna.

In open-ocean settings, the organic flux to the sea floor is often considered as the most important parameter controlling benthic foraminiferal abundance and distribution (e.g. Altenbach, 1985, 1987; Corliss and Emerson, 1990; Gooday et al., 1990; Jorissen et al., 1995; Heinz et al., 2002; Diz et al., 2006; Gooday and Jorissen, 2012). For many foraminiferal species, there is an optimum range of organic input within which they reproduce, are competitive and attain their maximum abundance (Altenbach et al., 1999). Some species show a strong tolerance to hypoxia and flourish in oxygen-depleted environments (e.g. Mackensen and Douglas, 1989; Gooday et al., 2000; Bernhard and Gupta, 2003; Cardich et al., 2012; Mallon et al., 2012; Sergeeva et al., 2012). Various mechanisms could explain how foraminifera survive in these adverse conditions, which many macro- and mega-faunal animals are unable to tolerate. These include anaerobic metabolic pathways, bacterial symbionts, sequestration of chloroplasts, or proliferation of peroxisomes and mitochondria (Koho and Piña-Ochoa, 2012, and references therein). In recent studies, Risgaard-Petersen et al. (2006) and Pina-Ochoa et al. (2009) demonstrated the ability of some foraminiferal species to accumulate intracellular nitrate for use as an electron acceptor for respiration instead of oxygen.

In the Arabian Sea, "live" (Rose-Bengal-stained) benthic foraminifera have been mainly studied on the Oman margin (e.g. Stubbings, 1939; Hermelin and Shimmield, 1990; Naidu and Malmgren, 1995; Gooday et al., 2000) and the Pakistan margin (Jannink et al., 1998; Maas, 2000; Erbacher and Nelskamp, 2006; Schumacher et al., 2007; Larkin and Gooday, 2009; Larkin et al., 2014; Enge et al., 2014). In addition, a few studies have focused on other areas, such as the Murray Ridge (Pozzato et al., 2013; Caulle et al., 2014) and the central, eastern and western parts of the Arabian Sea (Kurbjeweit et al., 2000; Heinz and Hemleben, 2003, 2006).
Most of these studies agree that oxygen concentration and organic matter quality and quantity have a strong influence on the abundance and composition of foraminiferal faunas. However, due to the inverse relationship between these two parameters, their relative importance remains difficult to resolve.

Here, we provide the first account of the distribution and abundance of foraminifera across the poorly studied Indian margin in the eastern Arabian Sea (Fig. 1a). The Indian margin displays low sea-surface primary production through the entire monsoonal cycle compared to other Arabian Sea regions (Fig. 1b), suggesting that lower organic resources are available for the benthic foraminiferal faunas. In this context, the present paper focuses on how foraminiferal faunas on the Indian margin respond to the combination of organic-matter fluxes that are likely to be moderate (as indicated by satellite images of chlorophyll $a$ ) and extremely low oxygen concentration.

\section{Materials and methods}

\subsection{Study area}

\subsubsection{The oxygen minimum zone}

The Arabian Sea hosts one of the world's most intense OMZs (Helly and Levin, 2004) with almost anoxic conditions in its core $(<2 \mu \mathrm{M}$; Paulmier and Ruiz-Pino, 2009). This is the result of the semi-enclosed nature of the northern Arabian Sea, the relatively oxygen-poor intermediate water masses originating from the Persian Gulf, and the effects of the twiceyearly strong intensification of the monsoon system. During the southwest or summer monsoon (June-September), intense upwelling develops off Somalia and Oman, and off the southwestern coast of India, due to the anticyclonic surface water circulation. Upwelling leads to an increase of biological production in the photic zone (Fig. 1b; e.g. Ryther and Menzel, 1965; Haake et al., 1993; Rixen et al., 1996), which triggers a strong export of organic carbon to intermediate water depths, where it is intensely recycled and remineralised. A second maximum in primary production occurs during the northeast or winter monsoon (December-March) caused by the convective mixing of the upper water column (Fig. 1b; e.g. Banse and McClain, 1986; Madhupratap et al., 1996; Caron and Dennett, 1999; Rixen et al., 2000). The highly eutrophic surface waters during monsoon periods contrast with the much less fertile conditions during the intermonsoon periods, especially in spring (Fig. 1b). Due to monsoons and their associated change in sea-surface circulation (cyclonic during the northeast monsoon and anticyclonic during the southwest monsoon), concentration of sea-surface primary production is different between regions and seasons (Fig. 1b). Sea-surface biological production is generally be- 
A
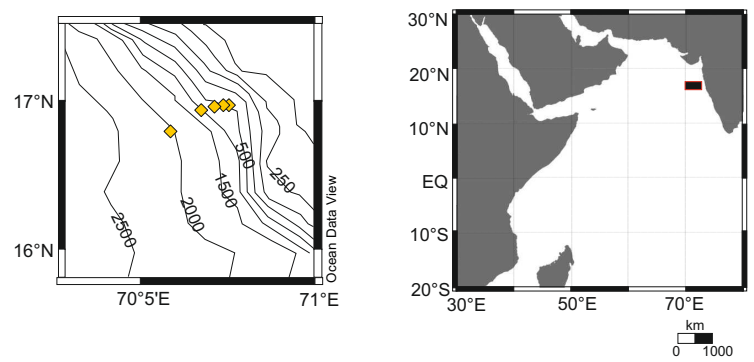

B
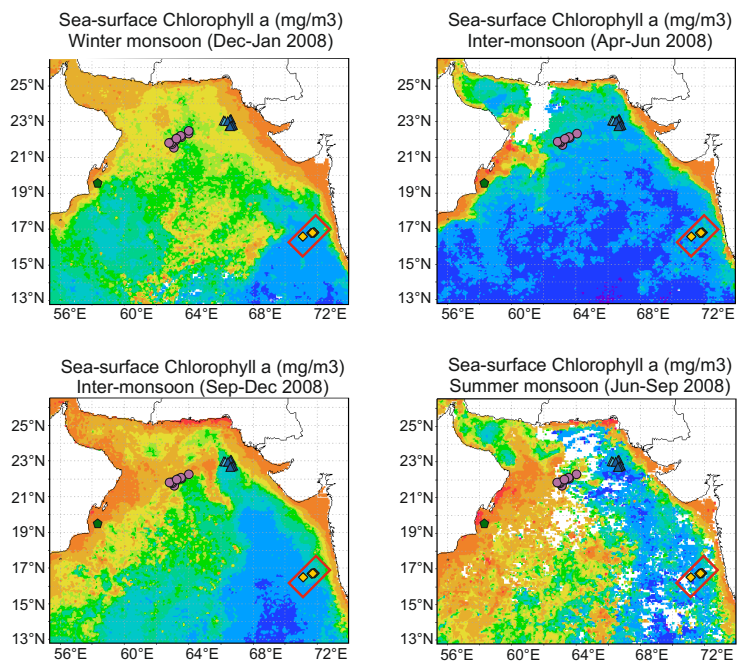

Chla $(\mathrm{mg} / \mathrm{m} 3)$

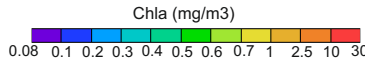

OMZ, which extends from 150 to $1300 \mathrm{~m}$ water depth on the Indian margin. Below is a brief summary of the main environmental characteristics of the OMZ relevant to our study.

1. In the core of the OMZ, at 535 and $649 \mathrm{~m}$ water depths, bottom-water dissolved oxygen concentrations (BWO) are very low, 0.35 and $0.23 \mu \mathrm{M}$, respectively. These two sites are enriched in organic matter ( $\mathrm{wt} \% \mathrm{C}_{\mathrm{org}} \sim 3.2$ and $\sim 5.8 \%$, respectively) (Cowie et al., 2014). The high concentrations of total hydrolysable amino acid (THAA) $\left(\sim 48.8\right.$ and $79.9 \mu \mathrm{mol} \mathrm{g}^{-1}$, respectively) reflect the presence of high-quality, labile organic matter (Cowie et al., 2014).

2. At the lower boundary of the OMZ core, at about $800 \mathrm{~m}$ depth (BWO $\sim 2.2 \mu \mathrm{M}$ ), the sediment is still characterised by high organic matter content and quality (wt \% $\mathrm{C}_{\text {org }} \sim 5.6 \%$ and THAA $\sim 69.8 \mu \mathrm{mol} \mathrm{g}^{-1}$; Cowie et al., 2014).

3. In the lower transitional zone, around $1100 \mathrm{~m}$ depth, BWO is still low $(\sim 15 \mu \mathrm{M})$ but the organic matter quantity and quality start to decrease (wt $\% \mathrm{C}_{\mathrm{org}} \sim 4.4 \%$ and THAA $\sim 62.9 \mu \mathrm{mol} \mathrm{g}^{-1}$; Cowie et al., 2014).

4. Beneath the OMZ, at $2000 \mathrm{~m}$, well-oxygenated waters (BWO $\sim 136 \mu \mathrm{M})$ and poorer trophic conditions occur (wt $\% \mathrm{C}_{\text {org }} \sim 1 \%$ and THAA $\sim 17 \mu \mathrm{mol} \mathrm{g}^{-1}$; Cowie et al., 2014).

\subsection{Foraminiferal analysis}

Sediment samples were taken using push cores $(8.3 \mathrm{~cm}$ internal diameter, surface area $54.1 \mathrm{~cm}^{2}$ ) deployed from the Shinkai 6500 submersible. On board the Yokosuka, each core was sliced and each sediment slice was preserved in $8 \%$ borax-buffered formalin. The study of the benthic foraminiferal communities is based on an examination of the first two half-centimetre levels $(0-1 \mathrm{~cm})$.

In the laboratory, the fixed sediment from the $0-0.5$ and $0.5-1.0 \mathrm{~cm}$ layers was washed separately through 300 and $150 \mu \mathrm{m}$ screens and stained overnight on the sieve in Rose Bengal solution. The $<150 \mu \mathrm{m}$ size fractions were kept and stored in borax-buffered formalin for possible future analyses. The 150-300 and $>300 \mu \mathrm{m}$ fractions of the two sediment layers were sorted wet (in water) under a binocular microscope for all Rose-Bengal-stained foraminifera.

The Rose Bengal technique is considered to be an inexpensive and easy method to recognise foraminifera that were alive (or recently alive) when collected (Walton, 1952; Murray and Bowser, 2000). However, especially in low oxygen settings, the cell material may persist long after death, resulting in false positives (Corliss and Emerson, 1990; Bernhard, 2000). In order to minimise overestimation in the live foraminiferal counts, strict staining criteria were always applied. Specimens were considered "alive" only when all chambers, except for the last one or two, were well 
stained. Furthermore, doubtful specimens were compared with perfectly stained specimens of the same species and non-transparent agglutinated and miliolid taxa were broken to inspect their contents. Soft-shelled monothalamous taxa, which are largely undescribed, were included in the data analyses. All foraminifera were identified to the lowest possible taxonomic level and assigned to informal species categories for diversity analyses. Species identification followed previous studies from the Arabian Sea (e.g. Maas, 2000; Schumacher et al., 2007; Larkin and Gooday, 2009; Caulle et al., 2014; Taylor and Gooday, 2014). A special effort was made to discriminate hormosinacean species (the superfamily Hormosinacea includes genera with uniserial chambers such as Reophax, Hormosina, Hormosinella, and Nodosinella), extending the recent taxonomic study of Taylor and Gooday (2014), which was based on different material from the same sites as the present study. Deep-sea hormosinacean species are often difficult to identify; many are undescribed and some widely reported "species" represent complexes of morphologically similar species (i.e. morphotypes). Hence it was necessary to assign many species within the genera Hormosina, Reophax and the monothalamous genus Lagenammina to informal categories. In some cases, these are the same as those illustrated by Taylor and Gooday (2014) but others have not been recognised previously. Since foraminifera are extremely abundant in finer sediment fractions, we confined our study to the $>150 \mu \mathrm{m}$ faction of the $0-1 \mathrm{~cm}$ layer; see raw count table in the Supplement for more details.

For all stations, diversity indices, including species richness ( $S$; count of number of taxa in a sample), Shannon index $\left(H^{\prime} \log _{e}\right)$, and Evenness $(J)$ were calculated using the statistical software "PAST" (PAleontological STatistics; Version 2.14; Hammer et al., 2009). We use the term "entire live" to refer to all stained foraminifera, i.e. agglutinated and calcareous taxa combined.

\section{Results}

\subsection{Foraminiferal densities}

The total densities of live (Rose-Bengal-stained) foraminifera in the upper $1 \mathrm{~cm}$ layer $(>150-\mu \mathrm{m}$ fraction) decreased from $\sim 3000$ ind. $/ 50 \mathrm{~cm}^{2}$ at $535 \mathrm{~m}$ in the OMZ core to $\sim 300$ ind. $/ 50 \mathrm{~cm}^{2}$ at $2000 \mathrm{~m}$ below the OMZ (Fig. 2). Foraminifera were concentrated in the 150-300 $\mu \mathrm{m}$ fraction, which at most stations accounted for about threequarters of the total density. Faunas were dominated by multichambered agglutinated species, which represented between $48 \%(2000 \mathrm{~m})$ and $75 \%(649 \mathrm{~m})$ of the assemblages, whereas calcareous species did not exceed $32 \%(535 \mathrm{~m})$ of the total fauna (Fig. 2 and Table 1). The relative abundance of monothalamids was lowest $(2 \%)$ at $649 \mathrm{~m}$ and highest $(30 \%)$ at $2000 \mathrm{~m}$. The absolute densities of multicham-

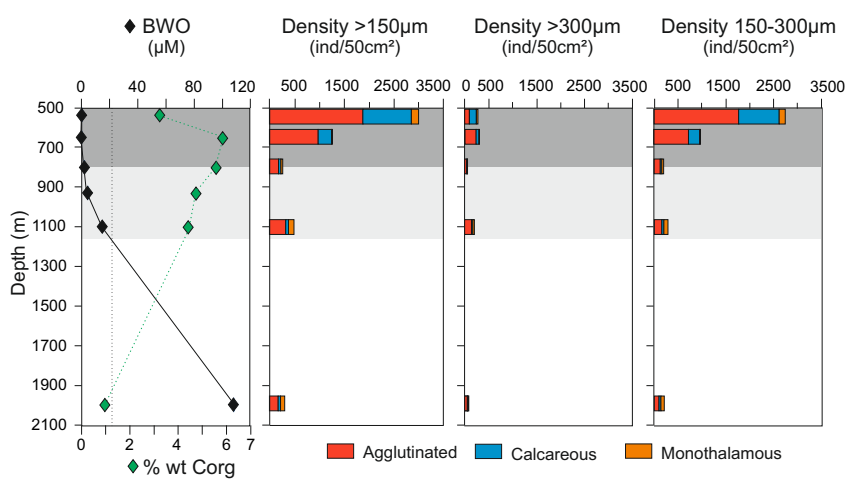

Figure 2. Total stained foraminiferal abundances (ind $/ 50 \mathrm{~cm}^{2}$ ) in the $150-300 \mu \mathrm{m},>300 \mu \mathrm{m}$ and $>150 \mu \mathrm{m}$ (i.e. $150-300$ and $>300 \mu \mathrm{m}$ combined) fractions of the first centimetre $(0-1 \mathrm{~cm}$ layer) along the sampling transect. The BWO concentration $(\mu \mathrm{M})$ and $\mathrm{C}_{\text {org }}$ content (wt. \%) are from Hunter et al. (2012) and Cowie et al. (2014). The vertical dashed line corresponds to the $22 \mu \mathrm{M}$ limits defining an OMZ according to Levin et al. (2003). The dark-grey shadow represents the core of the OMZ $(<2 \mu \mathrm{M}$; Paulmier and Ruiz-Pino, 2009) and the light-grey shadow the lower part of the OMZ $(2-22 \mu \mathrm{M}$; Levin, 2003).

bered agglutinated and calcareous species decreased with increasing water depth (Fig. 2). At $535 \mathrm{~m}$, in the core of the OMZ, their densities were $\sim 1870$ (agglutinated) and $\sim 990$ ind. $/ 50 \mathrm{~cm}^{2}$ (calcareous), respectively, compared to $\sim 150$ ind. $/ 50 \mathrm{~cm}^{2}$ and $\sim 55$ ind. $/ 50 \mathrm{~cm}^{2}$ at the deepest site $(2000 \mathrm{~m})$. Monothalamids did not show clear trends along the transect. The highest densities were found in the core $\left(535 \mathrm{~m} ; \sim 150\right.$ ind. $\left./ 50 \mathrm{~cm}^{2}\right)$ and in the lower part $(1100 \mathrm{~m}$; $\sim 115$ ind. $\left./ 50 \mathrm{~cm}^{2}\right)$ of the OMZ. The lowest densities $(\sim 25$ ind. $/ 50 \mathrm{~cm}^{2}$ ) were found at the $649 \mathrm{~m}$ site.

\subsection{Species richness, diversity and dominance of living foraminiferal faunas}

A total of 214 morphospecies were identified (0-1 cm layer, $>150 \mu \mathrm{m}$ size fraction), of which 131 were agglutinated (77 referred to the superfamily Hormosinacea), 79 were hyaline and only 4 were miliolids. Monothalamous species, the majority of which were undescribed, were included in the diversity analysis.

Species richness $(S)$ of the entire live faunas varied along the transect (Fig. 3). In the core of the OMZ, a total of 72 species were recognised at $535 \mathrm{~m}$ compared to 62 species at $649 \mathrm{~m}$. Species richness increased at sites below the OMZ core to a maximum of 84 species at $1100 \mathrm{~m}$ (Fig. 3). In contrast to the number of multichambered agglutinated species, which more or less mirrored the total number of "live" species, calcareous species richness was more constant between sites, ranging from a maximum of 32 species at $535 \mathrm{~m}$ to a minimum of 25 at 649 and $2000 \mathrm{~m}$ (Fig. 3). The Shannon $\left(H^{\prime}\right)$ and Fisher's alpha indices showed a similar trend toward higher values at greater depth and more elevated oxy- 
Table 1. Top 10 ranked species at each site. The number to the right of each name indicate counts of specimens with the relative abundances $(\%)$ in brackets.

\begin{tabular}{|c|c|c|c|c|c|c|c|c|c|}
\hline \multicolumn{2}{|c|}{$\begin{array}{c}535 \mathrm{~m} \\
\text { BWO: } 0.35 \mu \mathrm{M}\end{array}$} & \multicolumn{2}{|c|}{$\begin{array}{c}649 \mathrm{~m} \\
\text { BWO: } 0.23 \mu \mathrm{M}\end{array}$} & \multicolumn{2}{|c|}{$\begin{array}{c}800 \mathrm{~m} \\
\text { BWO: } 2.2 \mu \mathrm{M}\end{array}$} & \multicolumn{2}{|c|}{$\begin{array}{c}1100 \mathrm{~m} \\
\text { BWO: } 15 \mu \mathrm{M}\end{array}$} & \multicolumn{2}{|c|}{$\begin{array}{c}2000 \mathrm{~m} \\
\text { BWO: } 108 \mu \mathrm{M}\end{array}$} \\
\hline Reophax sp. 7 & $1118(35.1)$ & Reophax sp. 7 & $329(24.5)$ & Reophax sp. 7 & $19(6.8)$ & R. horridus & $76(7.6)$ & Reophax sp. 29 & $12(3.7)$ \\
\hline Ammodiscus sp. 1 & $113(3.5)$ & R. bilocularis & $190(14.2)$ & Lagenammina sp. 1 & $18(6.4)$ & R. spiculifera & $53(5.3)$ & Lagenammina sp. 23 & $11(3.4)$ \\
\hline C. wiesneri & $104(3.3)$ & Reophax sp. 10 & $118(8.9)$ & Reophax sp. 10 & $18(6.4)$ & A. tenuimargo & $18(1.8)$ & $R$. aff. scorpiurus & $11(3.4)$ \\
\hline Eggerella sp. 2 & $97(3.1)$ & Eggerella sp. 2 & $90(6.7)$ & R. agglutinatus & $15(5.4)$ & Reophax sp. 13 & $15(1.5)$ & Reophax sp. 31 & $11(3.4)$ \\
\hline Lagenammina sp. 2 & $92(3)$ & Eggerella sp. 1 & $52(3.9)$ & Lagenammina sp. 13 & $14(5)$ & Reophax sp. 27 & $13(1.3)$ & Reophax sp. 5 & $10(3.1)$ \\
\hline Reophax sp. 10 & $77(2.4)$ & Lagenammina sp. 2 & 49 (3.6) & $R$. dentaliniformis & $12(4.3)$ & Reophax sp. 3 & $12(1.2)$ & R. contortus & $9(2.8)$ \\
\hline Trochammina sp. 1 & $62(2)$ & Ammodiscus sp. 1 & $46(3.4)$ & Cribrostomoides sp. & $11(4)$ & Semivulvulina sp. & $11(1.1)$ & E. foliaceus & $7(2.2)$ \\
\hline R. aff scorpiurus & $46(1.4)$ & C. wiesneri & $24(1.8)$ & Lagenammina sp. 5 & $9(3.2)$ & Lagenammina sp. 13 & $10(1)$ & Lagenammina sp. 25 & $6(1.8)$ \\
\hline Eggerella sp. 1 & $42(1.3)$ & Spiroplectammina sp. 2 & $17(1.3)$ & Reophax sp. 19 & $8(3)$ & Reophax sp. 10 & $9(0.9)$ & P. challengerii & $5(1.5)$ \\
\hline R. bilocularis & $35(1.1)$ & $\begin{array}{l}\text { R. bilocularis form } 2 \\
\text { E. trigona }\end{array}$ & $\begin{array}{r}14(1) \\
89(6.6)\end{array}$ & $\begin{array}{l}\text { Leptohalysis sp. } 2 \\
\text { Reophax sp. } 13\end{array}$ & $\begin{array}{l}7(2.5) \\
5(2.5)\end{array}$ & Reophax sp. 1 & $7(0.7)$ & R. dentaliniformis & $4(1.2)$ \\
\hline Cassidulina sp. 1 & $324(10.1)$ & Cassidulina sp. 1 & $42(3.1)$ & C. oolina & $10(3.6)$ & C. oolina & $6(0.6)$ & B. aculeata & $7(2.1)$ \\
\hline B. aff. dilatata & $216(6.8)$ & $N$. cf. umboniferus & $22(1.6)$ & C. auriculus & $4(1.4)$ & H. elegans & $4(0.4)$ & Gyroidina sp. 1 & $6(1.8)$ \\
\hline Praeglobobulimina sp. 1 & $161(5.1)$ & H. elegans & $19(1.4)$ & Bolivina sp. & $3(1.1)$ & G. subglobosa & $4(0.4)$ & B. alazensis & $5(1.5)$ \\
\hline H. elegans & $72(2.2)$ & L. cf. calcar & $18(1.3)$ & Globobulimina spp. & $3(1.1)$ & M. barleeanus & $4(0.4)$ & E. exigua & $5(1.5)$ \\
\hline$U$. peregrina & $72(2.2)$ & Globobulimina spp. & $17(1.3)$ & $N$. cf. umboniferus & $3(1.1)$ & P. bulloides & $4(0.4)$ & H. elegans & $5(1.5)$ \\
\hline$U$. ex. gr. U. semiornata & $39(1.2)$ & F. rotundata & $10(0,7)$ & P. quinqueloba & $3(1.1)$ & P. pupoides & $3(0.3)$ & P. bulloides & $4(1.2)$ \\
\hline$N$. cf. umboniferus & $36(1.1)$ & C. oolina & $9(0,7)$ & Pullenia sp. & $3(1.1)$ & Amphycorina spp. & $2(0.2)$ & C. brady & $3(0.9)$ \\
\hline P. quinqueloba & $25(0.8)$ & Praeglobobulimina sp. 1 & $9(0.7)$ & $B$. aff. dilatata & $2(0.7)$ & B. aculeata & $2(0.2)$ & G. subglobosa & $3(0.9)$ \\
\hline C. auriculus & $15(0.4)$ & Pullenia sp. & $9(0.7)$ & Cassidulina sp. 1 & $2(0.7)$ & C. auriculus & $2(0.2)$ & O. umbonata & $3(0.9)$ \\
\hline E. trigona & $11(0.3)$ & R. semiinvoluta & $9(0.7)$ & G. orbicularis & $2(0.7)$ & Cibicidoides sp. & $2(0.2)$ & P. murrhina & $2(0.6)$ \\
\hline
\end{tabular}

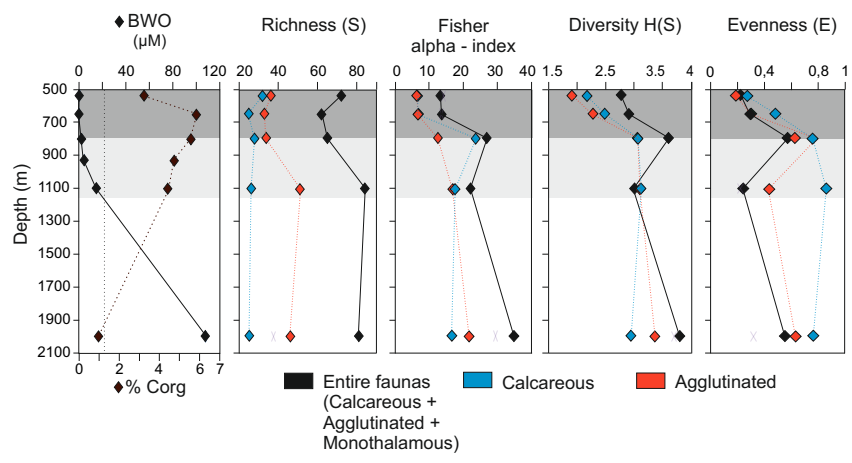

Figure 3. Stained foraminiferal diversity indices (in the $>150 \mu \mathrm{m}$ fraction) along the sampling transect. The $\mathrm{C}_{\text {org }}$ content (wt. \%) is from Hunter et al. (2012) and Cowie et al. (2014). The dashed line corresponds to the $22 \mu \mathrm{M}$ limit defining an OMZ according to Levin et al. (2003). The dark-grey shadow represent the core of the OMZ $(<2 \mu \mathrm{M}$; Paulmier and Ruiz-Pino, 2009) and the light-grey shadow the lower part of the OMZ (2-22 $\mu$ M; Levin, 2003).

gen concentration, but in contrast to species richness, these indices were higher for the entire live fauna at $800 \mathrm{~m}$ than at $1100 \mathrm{~m}$. The $1100 \mathrm{~m}$ site exhibited a lower $H^{\prime}$ value $(\sim 3)$ than the 800 and $2000 \mathrm{~m}$ sites (Fig. 3). In the case of the calcareous component, the trend in the Fisher index was broadly similar to that of the entire live assemblage with a distinct decrease from maximal values at $800 \mathrm{~m}$ to lower values at 1100 and $2000 \mathrm{~m}$. This pattern was not seen in the Shannon index, however (Fig. 3). For agglutinated taxa Shannon and Fisher indices were very similar between 800 and $1100 \mathrm{~m}$ (Fig. 3).

Evenness fluctuated along the transect (Fig. 3). There was an increase from low values at $535 \mathrm{~m}$ to a peak at $800 \mathrm{~m}$ in the total and multichambered agglutinated components, fol- lowed by a sharp decline to $1100 \mathrm{~m}$ with higher values again at $2000 \mathrm{~m}$. For calcareous species, evenness followed a similar trend down to $800 \mathrm{~m}$ but then increased further at $1100 \mathrm{~m}$, followed by somewhat lower values at $2000 \mathrm{~m}$. The evenness of the calcareous and agglutinated species was consistently higher than that of the entire live fauna. When considering calcareous and agglutinated species separately, diversity measures may be substantially different from those of the entire live fauna.

\subsection{Foraminiferal assemblage composition}

In general, the live faunas were mainly represented by perforate calcareous and agglutinated foraminifera. Soft-shelled monothalamous taxa were not considered in this analysis in order to allow a better comparison with previous studies.

Most of the abundant species were agglutinated, in many cases assigned to the genera Reophax and Lagenammina (Fig. 4a, Table 1). The agglutinated genus Ammodiscus, which belongs to a lineage that includes spirillinids and miliolids (Pawlowski et al., 2013), was common at the 535 and $649 \mathrm{~m}$ sites in the OMZ core. Relatively few of the species representing $>2 \%$ of the assemblages were calcareous (Fig. 4b, Table 1). Miliolids were very rare.

The faunal composition displayed important changes along the transect (Fig. 4). In general, different assemblages were observed at different sites, particularly in the case of the calcareous taxa. In the core of the OMZ (535 and $649 \mathrm{~m}$ ), where the oxygen concentration was very low, the agglutinated fauna was dominated by Reophax sp. 7, Reophax sp. 10, R. bilocularis, Lagenammina sp. 2, Eggerella sp. 1, Eggerella sp. 2, Cribrostomoides wiesneri and Ammodiscus sp. The most common calcareous species in the OMZ core were 

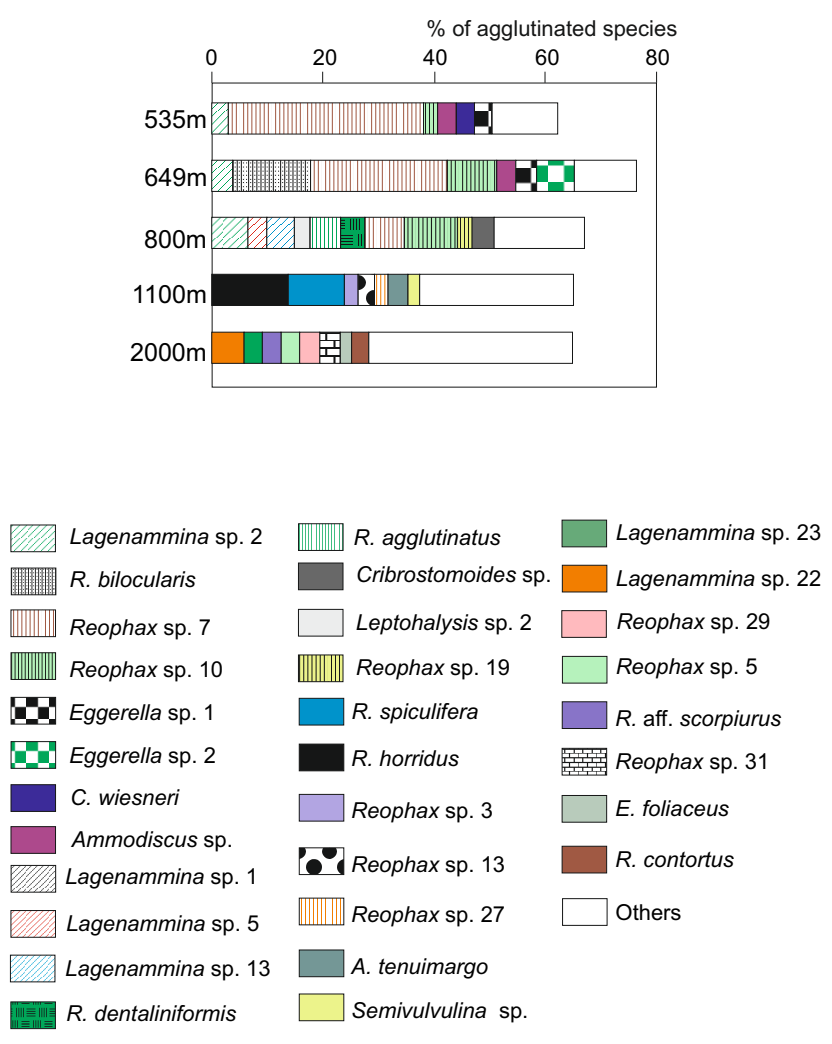

Figure 4. Relative abundances of "live" foraminiferal species in the $>150 \mu \mathrm{m}$ fraction of the top $1 \mathrm{~cm}$ layer at each station. (a) Agglutinated assemblage. (b) Calcareous assemblage. In each case, only the dominant species (> $2 \%$ at each station) are represented individually.

Bolivina aff. dilatata, Cassidulina sp. 1, Praeglobobulimina sp. 1, Hoeglundina cf. elegans, Uvigerina peregrina type parva at $535 \mathrm{~m}$, with Cassidulina sp. 1 and Ehrenbergina trigona at $649 \mathrm{~m}$ (Fig. 4b). The $800 \mathrm{~m}$ site had a very different fauna, mostly composed of Lagenammina spp. 1, 5 and 13, Reophax dentaliniformis, $R$. agglutinatus, Cribrostomoides sp. and Chilostomella oolina (Fig. 4). At $1100 \mathrm{~m}$, in the lower transition zone of the OMZ, two Reophax species, R. spiculifera and $R$. horridus, were predominant; other agglutinated species included Reophax spp. 3, 13 and 27, Ammoscalaria tenuimargo and Semivulvulina sp. 1. At this site, all calcareous species had relative abundances of less than $2 \%$. Finally, at the deepest site $(2000 \mathrm{~m})$, foraminiferal assemblages consisted mainly of Reophax aff. scorpiurus, Reophax spp. 5, 29 and 31, Lagenammina spp. 22 and 23, Recurvoides contortus, Bulimina aculeata and Hoeglundina cf. elegans (Fig. 4).

The cumulative percentage of all species representing $<2 \%$ of the "live" assemblages ("others" in Fig. 4a and b) was large, especially for the calcareous component, at sites below the core of the OMZ ( 800 to $2000 \mathrm{~m}$ ). Considering all sites across the transect together, only 8 calcareous species,
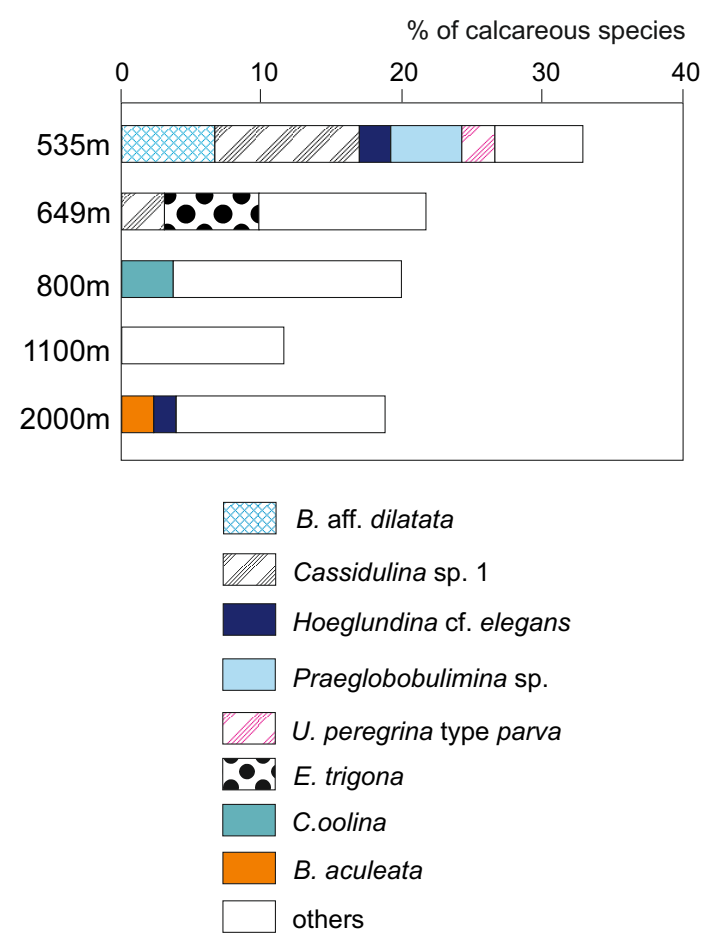

Figure 4. Continued.

out of a total of 83 , were sufficiently abundant to represent $>2 \%$ of the assemblage at least at one station (Fig. 4b).

\section{Discussion}

\subsection{Limitations of the study}

Our analyses were confined to the uppermost $(0-1 \mathrm{~cm})$ sediment layer, which would normally result in an underrepresentation of deeper-dwelling species. Foraminiferal microhabitats are largely controlled by organic matter input and oxygen penetration into the sediment (Corliss and Emerson, 1990; Jorissen et al., 1995). As a result, although foraminifera often occur in sediment layers down to a depth of $5 \mathrm{~cm}$ or more where oxygen is plentiful, they are generally concentrated near the sediment surface in hypoxic, organically enriched settings. Previous studies of the Arabian Sea OMZ core found most of the stained fauna in the first centimetre of the sediment (e.g. Jannink et al., 1998; Maas, 2000; Schumacher et al., 2007; Larkin and Gooday, 2009). In many hypoxic settings, compression of redox profiles leads to the absence of a well-defined vertical sequence of microhabitats and the presence of deep-infaunal taxa close to the sediment surface. Intermediate and deep infaunal taxa were scarce on the Indian margin, and have rarely been reported within the OMZ in previous Arabian Sea studies (Jannink et al., 1998; Kurbjeweit et al., 2000; Mass, 2000, Schumacher et al., 2007; Larkin et al., 2009; Caulle et al., 2014). In our 
material, Chilostomella oolina was the only species of this type that represented $>2 \%$ of the "live" fauna, being found mainly at $800 \mathrm{~m}$ (Fig. 4b). Similar observations were made by Schumacher et al. (2007) on the Pakistan margin, where C. oolina was found exclusively in the $0-0.5 \mathrm{~cm}$ layer across the OMZ (306-738 m depth). Species of the deep infaunal genus Globobulimina are also abundant in the first sediment centimetre on the Pakistan margin (at $576 \mathrm{~m}$; Erbacher and Nelskamp, 2006). These species occur at several centimetres in depth of the sediment in better oxygenated environments (Corliss and Emerson, 1990; Kitazato, 1994; Rathburn et al., 2000). Since our study was limited to the topmost centimetre of the sediment, it is possible that intermediate- and deepinfaunal species were missed at transitional sites and below the OMZ (1100 and $2000 \mathrm{~m}$ ). However, we think that it is unlikely that analysis of deeper sediment layers would have led to substantial changes of foraminiferal diversity, although density values may have slightly increased, especially at the deeper sites $(1100$ and $2000 \mathrm{~m})$. This view is supported by data in Caulle et al. (2014) from sites located along an oxygen gradient on the Murray Ridge (885 to $3010 \mathrm{~m}$ depth), where foraminiferal diversity was very similar in the $0-1$ and $0-10 \mathrm{~cm}$ sediment layers (> $150 \mu \mathrm{m}$ fraction).

Confining our analyses to the $>150 \mu \mathrm{m}$ size fraction introduces a second source of bias. In low oxygen settings, smallsized $(63-150 \mu \mathrm{m})$ foraminifera are particularly abundant (e.g. Jannink et al., 1998; Gooday et al., 2000; Schumacher et al., 2007), possibly because small species have a higher tolerance to low oxygen conditions (Caulle et al., 2014). However, the very considerable time and effort involved in sorting the dense populations present in size fractions $<150 \mu \mathrm{m}$ precluded their analysis in the present study. Even so, the $>150 \mu \mathrm{m}$ size fraction alone yielded abundant and diverse faunas with stained assemblages containing between 279 and 3177 individuals, belonging to 214 species. Moreover, Schumacher et al. (2007) and Caulle et al. (2014) demonstrated that adding the small-sized fraction $(63-150 \mu \mathrm{m})$ did not lead to a major change in bathymetric trends in foraminiferal diversity and faunal composition. Although analysing the finersize fractions may add some small-sized species, leading to slight changes in absolute and relative abundances, most of the species found in the small-size fraction occurred also in the coarser fraction. Finally, a major advantage of working on the $>150 \mu \mathrm{m}$ size fraction is that it allows direct comparison with palaeo-oceanographic studies, which are mainly based on the $>125$ or $>150 \mu \mathrm{m}$ fractions.

\subsection{Dense high-diversity assemblages in extreme hypoxic conditions}

On the basis of macrofaunal data from the Arabian Sea, Levin and Gage (1998) concluded that species dominance is related to the organic carbon flux to the sea floor, whereas species richness is mainly related to BWO concentrations. In a general sense and at a community scale, our Indian mar- gin density and diversity patterns confirm these conclusions; absolute densities were higher in the core of the OMZ than at deeper sites (Fig. 2) whereas diversity indices described the opposite trend (Fig. 3). Community densities have largely been discussed in previous studies carried in the Arabian Sea OMZ (e.g. Jannink et al., 1998; Gooday et al., 2000; Schumacher et al., 2007; Larkin et al., 2009; Caulle et al., 2014). On the Indian margin, trends in foraminiferal density across the OMZ are very similar to those reported in previous studies in the Arabian Sea and are explained by the large quantities of labile organic matter present in the OMZ sediments (Fig. 2). At the time of sampling (September-October 2008), the Indian margin OMZ was extremely hypoxic compared to previous observations in the Arabian Sea (e.g. Maas, 2000; Gooday et al., 2000; Schumacher et al., 2007; Larkin and Gooday, 2009; Vandewiele et al., 2009; Koho et al., 2013; Caulle et al., 2014). Oxygen concentrations in the core of the OMZ were $\sim 0.3$ compared to $\sim 2 \mu \mathrm{M}$ on the Murray Ridge (Pozzato et al., 2013; Koho et al., 2013; Caulle et al., 2014) and $\sim 4 \mu \mathrm{M}$ on the Pakistan margin (Schumacher et al., 2007; Larkin and Gooday, 2009). However, the performance of oxygen sensors is continuously improving, and detection limits are decreasing. As a result, discrepancies between studies may in part be due to instrumental bias, particularly when there is a substantial time lag between the different sampling periods.

In spite of the very low oxygen concentrations, species richness (i.e. the number of species) in our samples was surprisingly high, particularly at the most severely hypoxic site (535 m; Fig. 3), compared to previous data from the Arabian Sea (e.g. Jannink et al., 1998; Maas, 2000; Schumacher et al., 2007; Larkin and Gooday, 2009; Caulle et al., 2014). This difference may be the result of our unusually careful taxonomical analysis of the samples, which took into account monothalamids and the diverse hormosinaceans. These species are often difficult to identify and many are undescribed (Taylor and Gooday, 2014). A total of 77 hormosinacean species were recognised, based on the number of chambers, chamber shape and size, wall construction and the shape of the apertural neck. Similar careful taxonomy was applied to a sample from the core of the Oman margin OMZ (412 $\mathrm{m}$ depth), where BWO levels were more than 1 order of magnitude higher than off India, although still very low $(\sim 5.5$ vs. $\sim 0.35 \mu \mathrm{M})$ (Gooday et al., 2000 ). Foraminiferal species diversity and richness there were comparable to values reported in the present study $\left(H^{\prime}\left(\log _{e}\right) \sim 2.8, S=64\right)$, although the hormosinaceans were less diverse (Gooday et al., 2000).

Compared to the monothalamids and hormosinaceans, the taxonomy of calcareous foraminifera in the Arabian Sea is better known and their comparison with earlier studies is more straightforward. To facilitate comparisons with the data of Schumacher et al. (2007) and Caulle et al. (2014) diversity metrics were recalculated for calcareous species only (Fig. 6). These reveal that faunal diversity within (535 to 
$1100 \mathrm{~m}$ depth) and below (2000 m) the Indian margin OMZ is still higher than in other parts of the Arabian Sea. The high diversity in the core of the OMZ (Fig. 6), where oxygen concentrations were almost zero $(\sim 0.3 \mu \mathrm{M}$; at $535 \mathrm{~m})$ at the time of sampling, is particularly striking (Fig. 5). The presence at the $535 \mathrm{~m}$ site of a species that we assign to Hoeglundina cf. elegans is also very surprising (Fig. 4b). Based on a fossil record from the Murray Ridge (northern Arabian Sea) spanning the last 120000 years, den Dulk et al. (1998) concluded that $H$. elegans can tolerate mild hypoxia but not the severely hypoxic conditions found in the core of the OMZ. The occurrence of a morphologically similar species in the OMZ core on the Indian margin could be explained by the hydrodynamic setting of this region. At $535 \mathrm{~m}$, sharp-crested ripples (crests up to 10-12 cm high) were observed (Hunter et al., 2011; observations of U. Witte reported in Taylor and Gooday, 2014), indicating rapid water movements. A current speed of $15 \mathrm{~cm} \mathrm{~s}^{-1}$ was recorded here during the Yokosuka cruise (observations of $\mathrm{H}$. Nomaki, reported in Taylor and Gooday, 2014). Intermittent strong currents could lead to short periodic increases of BWO allowing low-oxygensensitive species such as $H$. cf. elegans to colonise the area, where they can apparently persist during the severely hypoxic periods. This hypothesis is supported by the occurrence at $535 \mathrm{~m}$ of numerous dead thyasirid bivalves and gastropods (between 150 and $300 \mu \mathrm{m}$ in size), which usually do not inhabit such severely oxygen-depleted environments (Levin, 2003). Thyasirids have been reported in the lower part of the OMZ on the Pakistan margin, where BWO varies between $\sim 4.5$ and $9 \mu \mathrm{M}$ (Oliver and Levin, 2006; Levin et al., 2009). Hoeglundina elegans is a commonly reported deep-sea species that is distributed across a wide bathymetric and geographical range in all oceans (Murray, 1991). Most records are from bathyal $(<3000 \mathrm{~m}$ ) or even sublittoral (e.g. $140 \mathrm{~m}$; Fontanier et al., 2002) depths, but morphologically identical specimens also occur at $>4000 \mathrm{~m}$ in the eastern equatorial Pacific (Gooday, unpublished data). The species found in the OMZ core on the Indian margin appears identical to typical examples of $H$. elegans in terms of test morphology. Nevertheless, we refer to it as $H$. cf. elegans because its occurrence in a severely hypoxic setting is unexpected, and for consistency with Enge et al. (2014). Whether it is genetically coherent with $H$. elegans from oxic environments in other oceans remains to be determined.

Another factor that could explain the high diversity of stained foraminifera in the OMZ core off India is the postmortem preservation of the cell material. In this severely hypoxic environment, the cytoplasm could persist for months or longer (Corliss and Emerson, 1990; Bernhard, 2000). Although, as explained above, strict staining criteria were applied, it might still be difficult to confidently discriminate between individuals that had been dead for some time and those that were alive when collected. More reliable assays, such as the CellTracker ${ }^{\mathrm{TM}}$ Green (CTG) technique (e.g. Bernhard, 2000; Bernhard et al., 2006), could give a better esti-

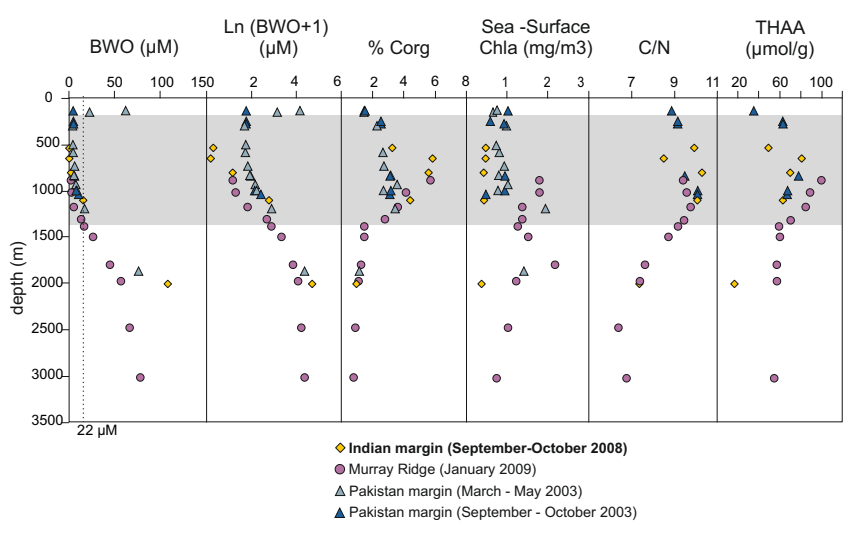

Figure 5. Regional comparison of the environmental parameters on the Indian and Pakistan margins and the Murray Ridge. The $\mathrm{C}_{\text {org }}$ content, $\mathrm{C} / \mathrm{N}$, THAA concentration data are from Hunter et al. (2012) and Cowie et al. (2014) for the Indian margin; from Vandewiele et al. (2009) for the Pakistan margin; from Koho et al. (2013) for the Murray Ridge. Because some values were $<1$, the BWO was expressed using the natural logarithm +1 $(\mathrm{Ln}(\mathrm{BWO}+1))$. The dark-grey shading corresponds to the OMZ.

mate of the "living" fauna. Alternatively, the temporal persistence of species that are not known for their tolerance of low oxygen conditions could be explained by a shift to anaerobic types of metabolism. Many foraminiferal species can accumulate intracellular nitrates in low oxygen settings (Piña-Ochoa et al., 2010), and some are able to respire these nitrates (Risgaard-Petersen et al., 2006). Unfortunately, no measurement of nitrate concentrations and denitrification rates are available for the dominant species of the Indian margin OMZ. Another possibility is that these foraminifera can lower their metabolism (i.e. become dormant) during the most adverse periods. Geslin et al. (2011) showed that most benthic foraminiferal species have low oxygen respiration rates per unit of cytoplasmic volume, estimated by assuming that the internal test volume corresponds to $75 \%$ of the total test volume (Hannah et al., 1994) and is entirely filled with cytoplasm.

\subsection{The tolerance of agglutinated foraminifera to low oxygen conditions}

Agglutinant foraminiferal species are often considered to be less tolerant of low oxygen conditions than calcareous foraminifera (Moodley et al., 1997; Gooday et al., 2000, 2001, 2009; Neira et al., 2001). However, this is not the case everywhere. In the Black Sea, soft-shelled monothalamids were more abundant than calcareous foraminifera in samples taken across the transition from hypoxic to sulfidic conditions (depth range 120-240 m; Sergeeva et al., 2012). On the Indian margin, agglutinated species are the dominant component (up to $76 \%$ at $649 \mathrm{~m}$ ) of foraminiferal assemblages. They include soft-shelled monothalamids, but the majority belong to genera such as Reophax and Hormosinella together 

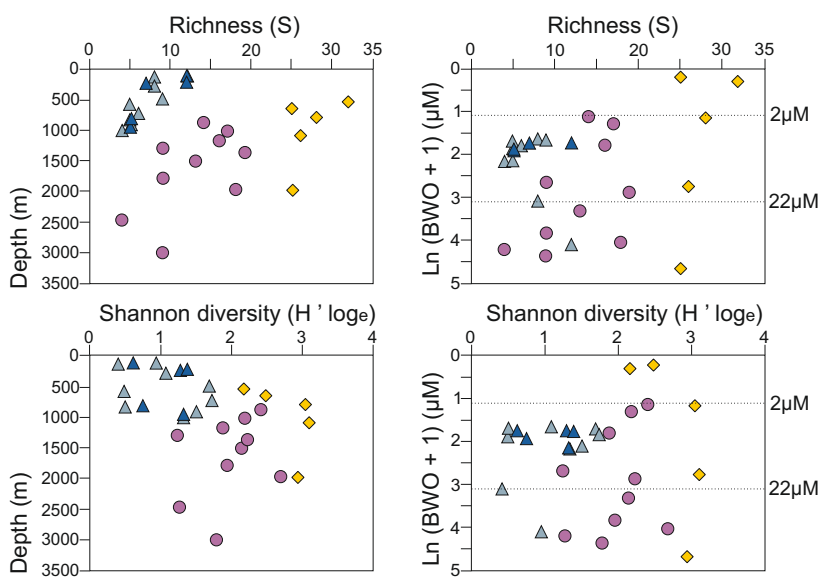

$\diamond$ Indian margin (post-summer monsoon 2008; this study) O Murray Ridge (winter monsoon 2009; Caulle et al., 2014) $\triangle$ Pakistan margin (spring intermonsoon 2003; Schumacher et al., 2007) A Pakistan margin (post-summer monsoon 2003; Schumacher et al., 2007)

Figure 6. Species richness and Shannon index (calculated for the calcareous fauna only) vs. depth (m) and Ln (BWO+1) for the Indian margin, the Pakistan margin and the Murray Ridge. Because some values were $<1$, the BWO was expressed using the natural logarithm $+1(\operatorname{Ln}(\mathrm{BWO}+1))$. The dash lines correspond to the limits of the OMZ core $(2 \mu \mathrm{M})$ and to the lower boundary of the OMZ $(22 \mu \mathrm{M})$.

with species of the single-chambered genus Lagenammina (Fig. 4b and Table 1). On the Indian margin, where oxygen concentrations during the Yokosuka cruise were extremely low in the $\mathrm{OMZ}$ core, these multichambered uniserial agglutinants are more abundant than calcareous foraminifera.

Previous studies have observed differences in foraminiferal composition related to sediment characteristics (e.g. Kaminski, 1985). The hydrodynamic context of the Indian margin, and particularly of sites in the $\mathrm{OMZ}$ core $(535$ to $800 \mathrm{~m})$, influences sediment grain size. At the $535 \mathrm{~m}$ site, the sand fraction represents $44 \%$ of the sediment compared to $9.6 \%$ at $800 \mathrm{~m}$ (Levin et al., 2013). Therefore, it is possible that the dominance of hormosinacean species at the $\mathrm{OMZ}$ sites is partly a consequence of the relatively coarse sediment. However, hormosinaceans, together with Lagenammina, are common in many fine-grained, deep-sea settings (e.g. Gooday et al., 2010b). In the Arabian Sea, similar proportions of Reophax and Lagenammina species have been reported in and below the OMZ on the Murray Ridge (Caulle et al., 2014) and the Oman margin (Gooday et al., 2000), and in the core of OMZ on the Pakistan margin (Larkin and Gooday, 2009; Fig. 6). The general abundance of hormosinacean species associated with the Arabian Sea OMZ suggests that it cannot be attributed to sediment grain size alone. In fact, these observations reinforce our conclusion that some hormosinaceans can tolerate strong oxygen depletion (Caulle et al., 2014).
Nevertheless, a tolerance to hypoxia does not fully explain why hormosinacean and Lagenammina species are so common in our samples. One possible explanation is that it is related to the quality of the available organic matter. Many agglutinated foraminifera seem to be less dependent on fresh food inputs than calcareous taxa, feeding instead on more refractory material (e.g. Gooday, 2003; Gooday et al., 2008; Koho, 2008; Koho et al., 2008; Phipps et al., 2012; Caulle et al., 2014). Another possible factor is that enhanced organic matter recycling and associated $\mathrm{CO}_{2}$ release into the porewaters depresses $\mathrm{pH}$ within OMZs (Gooday et al., 2010a), making the secretion of a carbonate test more energetically demanding. Seawater $\mathrm{pH}$ is reduced to below 7.1 on the Oman margin between 391 and 1265 m (Milliman et al., 1999). Taylor and Gooday (2014) observed that some globigerinacean shells incorporated in the tests of stained Reophax and Lagenammina specimens at our 535 and $800 \mathrm{~m}$ sites were partly corroded, and traces of dissolution were evident in our material as well. It is clear, however, that different hormosinacean and Lagenammina species display different degrees of tolerance to hypoxia on the Indian margin. For instance, Reophax spp. 7 and 10 were mainly found in the core (535$800 \mathrm{~m}$ depth; Fig. 4a and Table 1), and appear to be particularly well adapted to oxygen-poor conditions. It is possible that they have a facultative anaerobe metabolism. It has been demonstrated that some foraminiferal species may use nitrate as a second source of electron acceptor for respiration (denitrification; Risgaard-Petersen et al., 2006; Piña-Ochoa et al., 2010). In fact, Piña-Ochoa et al. (2010) showed that some agglutinated foraminifera collect nitrate, although only four Reophax specimens (three Reophax micaceus from the Bay of Biscay and one Reophax sp. from the Peru OMZ) were measured and no nitrate pool was detected. It can be suggested that hormosinacean species from the Arabian Sea $\mathrm{OMZ}$ are able to denitrify to thrive under this severe environment. However, further investigations are needed before any firm conclusions can be made on this topic.

Unlike Reophax spp. 7 and 10, Reophax aff. scorpiurus, Reophax spp. 31 and 5 were confined to the deepest site (2000 m; Fig. 4a and Table 1). Indeed, these species are abundant and diverse in many deep-sea environments, including fully oxic abyssal plains (e.g. Gooday et al., 2010b).

\subsection{Distribution of species across the OMZ}

There is a succession of both calcareous and agglutinated foraminiferal species along the OMZ transect (Fig. 4 and Table 1). Sites in the OMZ core (535 and $649 \mathrm{~m}$ ) have rather similar assemblages and are dominated (>2\%) by Reophax spp. 7 and 10 and Ammodiscus sp. 1 (agglutinated), and Cassidulina sp. 1, Bolivina aff. dilatata, Praeglobobulimina sp. 1, Hoeglundina cf. elegans and Ehrenbergina trigona (calcareous; Fig. 4 and Table 1). Most of these species are restricted to these two sites where oxygen concentrations were extremely low at the time of sampling $(\mathrm{BWO} \sim 0.2$ and 
$0.3 \mu \mathrm{M})$. The calcareous species, except for $H$. cf. elegans (see above), are typical of organically enriched environments with low oxygen concentrations (Bernhard and Gupta, 2003). Many of them (Hoeglundina cf. elegans as well as Uvigerina peregrina, Cassidulina sp. 1 and Praeglobobulimina sp. 1) demonstrated a large and rapid ( $\sim 4$ days) carbon uptake in tracer experiments on the Indian margin using labelled phytodetritus (Enge et al., 2014). Uvigerina ex. gr. U. semiornata exhibited a similar response in experiments conducted on the Pakistan margin in 2003 (Larkin et al., 2014). The ability of these species to feed rapidly on organic matter under extremely low oxygen concentrations may lead to the development of large population densities.

The lower boundaries of OMZs are often characterised by enhanced biogeochemical activity (Paulmier and Ruiz-Pino, 2009) and elevated faunal abundance in both the benthic and pelagic communities (e.g. Sanders and Hessler, 1969; Mullins et al., 1985; Ward et al., 1989; Levin et al., 1991; Wishner et al., 1995; Levin, 2003). On the Pakistan margin an edge effect of this kind was evident among foraminiferal populations at around $750 \mathrm{~m}$ depth (Gooday et al., 2009) and might therefore be expected at our $800 \mathrm{~m}$ site (BWO $\sim 2.2 \mu \mathrm{M}$ ). Hence it is rather surprising that faunal density are minimal here $\left(\sim 320 \mathrm{ind} / 50 \mathrm{~cm}^{2} ;\right.$ Fig. 2). If foraminifera do exhibit an edge effect on the Indian margin it must be at some depth between $800 \mathrm{~m}$ and the next deepest site at $1100 \mathrm{~m}$.

The assemblage at $800 \mathrm{~m}$ comprises a mixture of calcareous species typical of the OMZ core (e.g. Bolivina aff. dilatata, Cassidulina sp. 1) and those that are more widely distributed (e.g. Cancris auriculus, Chilostomella oolina), together with Reophax spp. 7 and 10 and Lagenammina sp. 1 (Fig. 4 and Table 1). Apparently, the oxygen concentration here is still low enough to allow species adapted to the core of the OMZ to remain competitive, but also high enough to allow taxa such as Cancris auriculus and Chilostomella oolina to colonise the site, resulting in maximum diversity. Cancris auriculus is also found in the OMZ (BWO $\sim 5 \mu \mathrm{M}$ ) on the Pakistan margin (Larkin and Gooday, 2009). A different foraminiferal assemblage is observed in the lower part of the OMZ (1100 m; BWO $\sim 15 \mu \mathrm{M})$, where Reophax horridus, Reophax spiculifera, Reophax sp. 10, Chilostomella oolina, Hoeglundina cf. elegans, Globocassidulina subglobosa and Bulimina aculeata (Fig. 4 and Table 1) are all abundant. Most of these species are widely distributed in the bathyal deep sea and, except for $H$. cf. elegans, they are not found in the OMZ core. An inability to tolerate very low oxygen concentrations, perhaps combined with strong competition from better adapted species, probably precludes their penetration into this harsh environment. It thus appears that there is a critical oxygen threshold between $\sim 2$ and $\sim 15 \mu \mathrm{M}$ (i.e. 800 and $1100 \mathrm{~m}$ depth) for benthic foraminifera on our Indian margin transect. Due to the sample site spacing, it is difficult to specify a more precise value.
Changes in the composition of foraminiferal assemblages are also observed in other areas of the Arabian Sea. On the Pakistan margin, Schumacher et al. (2007) found transitional assemblages, mainly composed of Bolivina aff. dilatata, Praeglobobulimina sp. 1, Uvigerina peregrina and Chilostomella oolina, between $\sim 600$ and $\sim 800 \mathrm{~m}$ (BWO $4.7-5.8 \mu \mathrm{M})$, a depth range spanning the lower part of the OMZ core and the upper part of the "lower transition zone" (Gooday et al., 2009). On the Murray Ridge, this change occurs at $1172-1306 \mathrm{~m}(\mathrm{BWO} \sim 5.0-13.8 \mu \mathrm{M})$ where the widely distributed species (e.g. Globocassidulina subglobosa, Ehrenbergina trigona, Fursenkoina spp.) occur together with species typical of the OMZ core that may have more restricted distributions (e.g. Ammodiscus sp. 1; Caulle et al., 2014). These studies are consistent with the existence of a transitional assemblage where the BWO starts to increase, either at the base of the OMZ core or around the lower boundary of the OMZ.

\subsection{BWO, deposit and flux of organic matter and benthic foraminiferal faunas: comparison of study sites}

Compared to previous studies in the Arabian Sea (e.g. Maas, 2000; Gooday et al., 2000; Schumacher et al., 2007; Vandewiele et al., 2009; Larkin and Gooday, 2009; Koho et al., 2013; Caulle et al., 2014), the OMZ of the Indian margin appears to be more severely depleted of oxygen, in view of possible bias due to instrumental development. In fact, conditions here were virtually anoxic, at least during the sampling period. On the other hand, the similar values for surface sediment organic matter quantity and quality (THAA content) between study areas suggest an absence of major regional differences in these parameters (Fig. 5; Vandewiele et al., 2009; Koho et al., 2013; Cowie et al., 2014). This is surprising in view of the concentrations of sea-surface chlorophyll $a$, mirroring primary production, which are much lower on the Indian margin compared to the rest of the Arabian Sea (Fig. 1b). The comparably high $\mathrm{C}_{\text {org }}$ values of the superficial sediments here (in contrast to the low surface water PP) could be partly explained by the lower-oxygen concentrations on the Indian margin (Fig. 5) coupled to local hydrodynamics (seasonal development of a belt of intense oxygen depletion linked to northward surface currents) leading to a better preservation of organic matter (Cowie et al., 2014). This would imply that the availability of labile organic carbon on the Indian margin is only partly determined by the sea-surface primary productivity. Instead, severe mid-water hypoxia leading to limited organic matter degradation during transit through the water column may play an important role in the presence of abundant high-quality organic matter $(\mathrm{OM})$ on the sea floor. However, it has to be kept in mind that there are many indicators of OM quality (e.g. THAA, concentration of a single amino acid, enzymatically hydrolysable amino acids) and their interpretations are often problematic. 

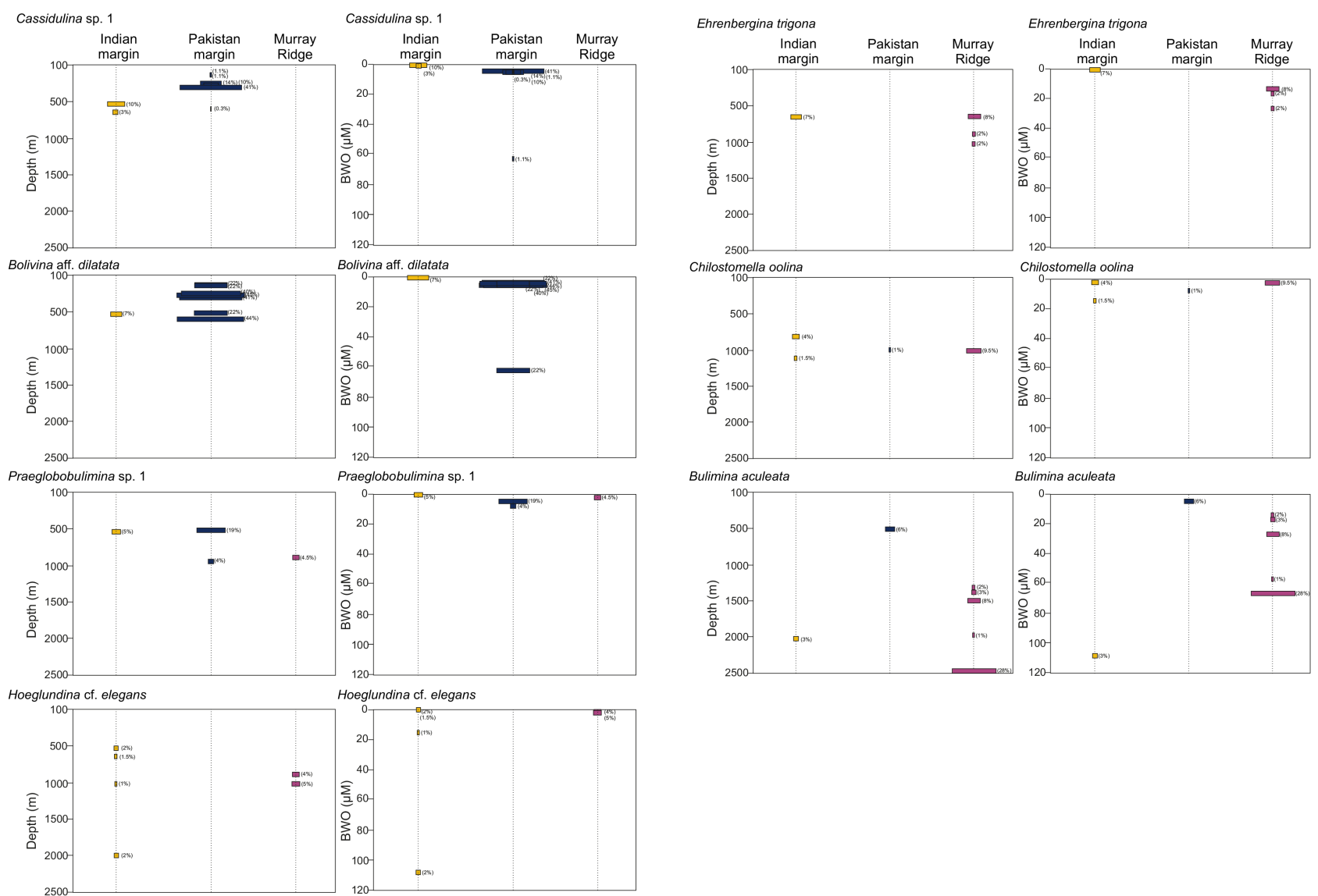

Figure 7. Comparison of species occurrences vs. depth (left panel) and BWO ( $\mu \mathrm{M}$; right panel) for three regions in the Arabian Sea. Cassidulina sp. 1 (from the Indian margin) and Cassidulina laevigata (Schumacher et al., 2007) were grouped into Cassidulina sp. Percentage species occurrences are indicated in brackets.

It is not clear how these indices describe the bioavailability of the organic components. Nevertheless, we think that our data suggest that on the Indian margin, BWO as well as hydrodynamics represent a more important control on benthic foraminiferal abundance and species composition than seasurface primary production.

The same foraminiferal species are found on the Indian margin and at previously studied sites in the Arabian Sea (Fig. 7). Praeglobobulimina sp. 1 is restricted to extremely low oxygen concentrations $(<10 \mu \mathrm{M})$, mainly corresponding to the core of the OMZ on the Indian margin, the Murray Ridge and the Pakistan margin, while Cassidulina sp. 1 and Bolivina aff. dilatata are generally found at oxygen concentrations $<10 \mu \mathrm{M}$ (Fig. 7). This highlights the strong adaptation of these indicator species to hypoxic environments. Praeglobobulimina sp. 1 and $B$. aff. dilatata have not been reported in other oceanic basins, including the OMZ in the East Pacific or the well-studied upwelling area off northwest Africa. This raises the issue of whether some species inhabiting OMZs are endemic to particular regions. It has been suggested that severely stressed environments, notably those stressed by extreme hypoxia, may induce rapid morphologi- cal and genetic changes (Verhallen, 1987) as well as promoting allopatric speciation through the creation of barriers to gene flow (Rogers, 2000). The visually conspicuous spider crab Encephaloides armstrongii is an example of a species that appears to be restricted to the OMZ in the northern Arabian Sea and Bay of Bengal (Creasey et al., 1997). However, the question of endemism within OMZ settings needs to be explored through a combination of molecular genetics and morphological analysis.

Ehrenbergina trigona and Chilostomella oolina appear in a BWO interval from $\sim 0$ to $\sim 22 \mu \mathrm{M}$ (Fig. 7). It appears that many Arabian Sea foraminiferal species are living in a specific range of BWO concentrations, defining ecological niches for the different species. The fact that the same species occur on the Indian margin, the Pakistan margin and the Murray Ridge, in the same BWO interval, but probably with very different export production (based on satellite images of chlorophyll $a$ ), provides support for the dominant role of BWO, rather than organic flux to the sea floor, in regulating the benthic foraminiferal assemblages. 


\subsection{Implications in palaeo-oceanography}

Our results suggest that BWO may play the major role in regulating benthic foraminiferal assemblages in the Arabian Sea. This conclusion could have important implications for the reconstruction OMZ variability in the Arabian Sea over geological timescales. Foraminiferal marker species typical of the OMZ (Praeglobobulimina sp. 1, Cassidulina sp. 1, Bolivina aff. dilatata, Ehrenbergina trigona) should provide critical and reliable information about past BWO, making it possible to quantitatively reconstruct past changes in intensity and extension of the OMZ. On the other hand, some species, such as Bulimina aculeata and Hoeglundina cf. elegans, are both found in the OMZ and below (Fig. 7). It seems that the ecological preferences of these two species differ from site to site. This could suggest a high adaptability of these two species to several environmental conditions (BWO and organic carbon). It could also be the result of the presence of cryptic species, with a very similar morphology. However, due to their wide ecological range, Bulimina aculeata and Hoeglundina cf. elegans cannot be used as tracers of past oxygen concentrations. Additionally, absolute foraminiferal diversity indices have to be interpreted very carefully in palaeo-reconstructions from the Arabian Sea, as our results show that low BWO is not always synonymous with low foraminiferal diversity.

\section{Conclusions}

This study focused on the response of living (Rose-Bengalstained) benthic foraminifera to the combination of low organic-matter fluxes and extremely low oxygen concentrations on the poorly studied Indian margin. A transect through the OMZ yielded a dense and relatively diverse live assemblage in the extreme hypoxic conditions prevailing at $535 \mathrm{~m}$ in the OMZ core and a much sparser but more diverse assemblage in well-oxygenated waters at $2000 \mathrm{~m}$ depth, below the OMZ. The unexpectedly high diversity in the OMZ core, which contradicts the commonly accepted paradigm of low oxygen areas being characterised by low-diversity faunas, may reflect the adaptation of the predominantly agglutinated species present here to these extreme conditions. However, this high diversity in the $\mathrm{OMZ}$ may also result from periods of higher oxygenation mediated by the activity of bottom currents in this region. The presence of Hoeglundina cf. elegans and dead thyasariid bivalves supports the hypothesis of strong intermittent oxygen fluctuations. Moreover, extremely low oxygen concentrations may enhance the preservation of cellular material after the death of the organism, increasing the apparent diversity of the Rose-Bengal-stained assemblage.

The high abundances of Reophax and Lagenammina species suggest that these agglutinated foraminifera species are more tolerant to low oxygen settings than previously thought. Although their ecology is not well understood, their presence may be related to the quality and quantity of the organic matter within the OMZ. However, foraminiferal assemblages (both agglutinated and calcareous taxa) change along the oxygen transect. An assemblage comprising species tolerant of severe hypoxia in the core of the OMZ is succeeded by a transitional assemblage in the lower part of the OMZ, and finally a fauna composed of more widely distributed species below the OMZ. We suggest that this faunal succession is mainly controlled by the bottom-water oxygen concentrations. There appears to be an oxygen threshold between 2 and $15 \mu \mathrm{M}$ that separates foraminifera typical of the hypoxic core, which probably have a restricted (endemic) distribution, from more cosmopolitan species that are less tolerant of hypoxia and characterise the deeper sites.

A comparison of benthic foraminiferal assemblages from the Indian margin with those reported in previous studies from other parts of the Arabian Sea suggests that similar species are common at sites with the same bottom-water oxygenation but subject to different organic-matter flux regimes. Thus bottom-water oxygen levels may exert the main control on species distributions in this region. This would enhance the utility of foraminiferal species as reliable tools to reconstruct past OMZ variability in the Arabian Sea.

\section{The Supplement related to this article is available online at doi:10.5194/bg-12-5005-2015-supplement.}

Acknowledgements. We thank the captain and crew of the RV Yokosuka and the pilots and staff of the Shinkai 6500 human-occupied vehicle for their assistance with the field operations. We thank the scientists participating in the RV Yokosuka cruise YK08-11 for their assistance, especially Kazumasa Oguri and Hisami Suga, who measured dissolved oxygen concentrations, and Will Hunter, Lisa Levin, Hidetaka Nomaki, Ursula Witte and Claire Woulds, who helped with the faunal work at sea. We are grateful for the comments of Anthony Rathburn and two anonymous reviewers, which helped to substantially improve the original submission.

Edited by: L. Levin

\section{References}

Altenbach, A. V.: Die Biomasse der benthische Foraminiferen, in Auswertungen von "Meteor"-Expeditionen im östliche Nordatlantik, University of Kiel, Ph.D. diss., 1985.

Altenbach, A. V.: The measurement of organic carbon in foraminifera, J. Foramin. Res., 17, 106-109, 1987.

Altenbach, A. V., Pflaumann, U., Schiebel, R., Thies, A., Timm, S., and Trauth, M.: Scaling percentages and distributional patterns of benthic foraminifera with flux rates of organic carbon, J. Foramin. Res., 29, 173-185, 1999. 
Banse, K. and McClain, C. R.: Winter blooms of phytoplankton in the Arabian Sea as observed by the Coastal Zone Color Scanner, Ma. Ecol.-Prog. Ser., 34, 201-211, 1986.

Bernhard, J. M.: Distinguishing Live from Dead Foraminifera: Methods Review and Proper Applications, Micropaleontology, 46, 38-46, 2000.

Bernhard, J. M. and Gupta, B. K. S.: Foraminifera of oxygen-depleted environments, in Modern Foraminifera,201216, Springer, Netherlands, 2003.

Bernhard, J. M., Ostermann, D. R., Williams, D. S., and Blanks, J. K.: Comparison of two methods to identify live benthic foraminifera: A test between Rose Bengal and CellTracker Green with implications for stable isotope paleoreconstructions, Paleoceanography, 21, PA4210, doi:10.1029/2006PA001290, 2006.

Cardich, J., Morales, M., Quipúzcoa, L., Sifeddine, A., and Gutiérrez, D.: Benthic Foraminiferal Communities and Microhabitat Selection on the Continental Shelf Off Central Peru, in: Anoxia, edited by: Altenbach, A. V., Bernhard, J. M., and Seckbach, J., 323-340, 2012

Caron, D. A. and Dennett, M. R.: Phytoplankton growth and mortality during the 1995 Northeast Monsoon and Spring Intermonsoon in the Arabian Sea, Deep-Sea Res. Pt. II, 46, 1665-1690, 1999.

Caulle, C., Koho, K. A., Mojtahid, M., Reichart, G. J., and Jorissen, F. J.: Live (Rose Bengal stained) foraminiferal faunas from the northern Arabian Sea: faunal succession within and below the OMZ, Biogeosciences, 11, 1155-1175, doi:10.5194/bg-111155-2014, 2014.

Cook, P. L., Revill, A. T., Butler, E. C., and Eyre, B. D.: Carbon and nitrogen cycling on intertidal mudflats of a temperate Australian estuary. II. Nitrogen cycling, Ma. Ecol.-Prog. Ser., 280, 39-54, 2004.

Corliss, B. H. and Emerson, S.: Distribution of rose bengal stained deep-sea benthic foraminifera from the Nova Scotian continental margin and Gulf of Maine, Deep-Sea Res., 37, 381-400, doi:10.1016/0198-0149(90)90015-N, 1990.

Cowie, G., Mowbray, S., Kurian, S., Sarkar, A., White, C., Anderson, A., Vergnaud, B., Johnstone, G., Brear, S., Woulds, C., Naqvi, S. W. A., and Kitazato, H.: Comparative organic geochemistry of Indian margin (Arabian Sea) sediments: estuary to continental slope, Biogeosciences, 11, 6683-6696, doi:10.5194/bg-11-6683-2014, 2014.

Creasey, S., Rogers, A. D., Tyler, P., Young, C., and Gage, J.: The population biology and genetics of the deep-sea spider crab, Encephaloides armstrongi Wood-Mason 1891 (Decapoda: Majidae), Philos. T. R. Soc. B, 352, 365-379, 1997.

Den Dulk, M., Reichart, G. J., Memon, G. M., Roelofs, E. M. P., Zachariasse, W. J., and van der Zwaan, G. J.: Benthic foraminiferal response to variations in surface water productivity and oxygenation in the northern Arabian Sea, Mar. Micropaleontol., 35, 43-66, doi:10.1016/S0377-8398(98)00015-2, 1998.

Diz, P., Francés, G., and Rosón, G.: Effects of contrasting upwelling-downwelling on benthic foraminiferal distribution in the Ría de Vigo (NW Spain), J. Mar. Sys., 60, 1-18, 2006.

Enge, A. J., Witte, U., Kucera, M., and Heinz, P.: Uptake of phytodetritus by benthic foraminifera under oxygen depletion at the Indian margin (Arabian Sea), Biogeosciences, 11, 2017-2026, doi:10.5194/bg-11-2017-2014, 2014.

Erbacher, J. and Nelskamp, S.: Comparison of benthic foraminifera inside and outside a sulphur-oxidizing bacterial mat from the present oxygen-minimum zone off Pakistan (NE Arabian Sea), Deep-Sea Res. Pt. I, 53, 751-775, doi:10.1016/j.dsr.2006.02.003, 2006.

Fontanier, C., Jorissen, F. ., Licari, L., Alexandre, A., Anschutz, P., and Carbonel, P.: Live benthic foraminiferal faunas from the Bay of Biscay: faunal density, composition, and microhabitats, DeepSea Res. Pt. I, 49, 751-785, doi:10.1016/S0967-0637(01)000784, 2002.

Geslin, E., Risgaard-Petersen, N., Lombard, F., Metzger, E., Langlet, D., and Jorissen, F.: Oxygen respiration rates of benthic foraminifera as measured with oxygen microsensors, J. Exp. Mar. Biol. Ecol., 396, 108-114, doi:10.1016/j.jembe.2010.10.011, 2011.

Gooday, A. J. and Jorissen, F. J.: Benthic Foraminiferal Biogeography: Controls on Global Distribution Patterns in Deep-Water Settings, Annu. Rev. Mar. Sci., 4, 237-262, doi:10.1146/annurevmarine-120709-142737, 2012.

Gooday, A. J., Turley, C. M., and Allen, J. A.: Responses by Benthic Organisms to Inputs of Organic Material to the Ocean Floor: A Review and Discussion, Philos. T. R. Soc. A, 331, 119-138, 1990.

Gooday, A. J., Bernhard, J. M., Levin, L. A., and Suhr, S. B.: Foraminifera in the Arabian Sea oxygen minimum zone and other oxygen-deficient settings: taxonomic composition, diversity, and relation to metazoan faunas, Deep-Sea Res. Pt. II, 47 , 25-54, doi:10.1016/S0967-0645(99)00099-5, 2000.

Gooday, A. J., Kitazato, H., Hori, S., and Toyofuku, T.: Monothalamous Soft-Shelled Foraminifera at an Abyssal Site in the North Pacific: A Preliminary Report, J. Oceanogr., 57, 377-384, doi:10.1023/A:1012447015771, 2001.

Gooday, A. J., Nomaki, H., and Kitazato, H.: Modern deep-sea benthic foraminifera: a brief review of their morphology-based biodiversity and trophic diversity, Geological Society, London, Special Publications, 303, 97-119, 2008.

Gooday, A. J., Levin, L. A., Aranda da Silva, A., Bett, B. J., Cowie, G. L., Dissard, D., Gage, J. D., Hughes, D. J., Jeffreys, R., Lamont, P. A., Larkin, K. E., Murty, S. J., Schumacher, S., Whitcraft, C., and Woulds, C.: Faunal responses to oxygen gradients on the Pakistan margin: A comparison of foraminiferans, macrofauna and megafauna, Deep-Sea Res. Pt. II, 56, 488-502, doi:10.1016/j.dsr2.2008.10.003, 2009.

Gooday, A. J., Bett, B. J., Escobar, E., Ingole, B., Levin, L. A., Neira, C., Raman, A. V., and Sellanes, J.: Biodiversity and habitat heterogeneity in oxygen minimum zones, Mar, Ecol., 31, 125147, 2010a.

Gooday, A. J., Malzone, M. G., Bett, B. J., and Lamont, P. A.: Decadal-scale changes in shallow-infaunal foraminiferal assemblages at the Porcupine Abyssal Plain, NE Atlantic, Deep-Sea Res. Pt. II, 57, 1362-1382, 2010b.

Haake, B., Ittekkot, V., Rixen, T., Ramaswamy, V., Nair, R. R., and Curry, W. B.: Seasonality and interannual variability of particle fluxes to the deep Arabian Sea, Deep-Sea Res. Pt. I, 40, 1323 1344, 1993.

Hammer, Ø., Harper, D. A. T., and Ryan, P. D.: PASTPAlaeontological STatistics, ver. 1.89, University of Oslo, Oslo, 2009.

Hannah, F., Rogerson, A., and Laybourn-Parry, J.,: Respiration rates and biovolumes of common benthic foraminifera (protozoa), J. Mar. Biol. Assoc. UK, 74, 301-312, 1994. 
Heinz, P. and Hemleben, C.: Regional and seasonal variations of recent benthic deep-sea foraminifera in the Arabian Sea, DeepSea Res. Pt. I, 50, 435-447, doi:10.1016/S0967-0637(03)00014$1,2003$.

Heinz, P. and Hemleben, C.: Foraminiferal response to the Northeast Monsoon in the western and southern Arabian Sea, Mar. Micropaleontol., 58, 103-113, doi:10.1016/j.marmicro.2005.10.001, 2006.

Heinz, P., Hemleben, C., and Kitazato, H.: Time-response of cultured deep-sea benthic foraminifera to different algal diets, DeepSea Res. Pt. I, 49, 517-537, doi:10.1016/S0967-0637(01)00070X, 2002.

Helly, J. J. and Levin, L. A.: Global distribution of naturally occurring marine hypoxia on continental margins, Deep-Sea Res. Pt. I, 51, 1159-1168, doi:10.1016/j.dsr.2004.03.009, 2004.

Hermelin, J. O. R. and Shimmield, G. B.: The importance of the oxygen minimum zone and sediment geochemistry in the distribution of Recent benthic foraminifera in the northwest Indian Ocean, Mar. Geol., 91, 1-29, 1990.

Hunter, W. R., Oguri, K., Kitazato, H., Ansari, Z. A., and Witte, U.: Epi-benthic megafaunal zonation across an oxygen minimum zone at the Indian continental margin, Deep-Sea Res. Pt. I, 58, 699-710, 2011.

Hunter, W. R., Veuger, B., and Witte, U.: Macrofauna regulate heterotrophic bacterial carbon and nitrogen incorporation in lowoxygen sediments, ISME J., 6, 2140-2151, 2012.

Jannink, N. T., Zachariasse, W. J., and Van der Zwaan, G. J.: Living (Rose Bengal stained) benthic foraminifera from the Pakistan continental margin (northern Arabian Sea), Deep-Sea Res. Pt. I, 45, 1483-1513, doi:10.1016/S0967-0637(98)00027-2, 1998.

Jorissen, F. J., de Stigter, H. C., and Widmark, J. G. V.: A conceptual model explaining benthic foraminiferal microhabitats, Mar. Micropaleontol., 26, 3-15, doi:10.1016/0377-8398(95)00047-X, 1995.

Kaminski, M. A.: Evide for control of abyssal agglutinated community structure by substrate disturbance: results from HEBBLE Area, Mar. Geol., 66, 113-131, 1985.

Kitazato, H.: Foraminiferal microhabitats in four marine environments around Japan, Mar. Micropaleontol., 24, 29-41, 1994.

Koho, K. A.: The dynamic balance between food abundance and habitat instability: benthic foraminifera of Portuguese margin canyons, 2008.

Koho, K. A. and Piña-Ochoa, E.: Benthic Foraminifera: Inhabitants of Low-Oxygen Environments, in: Anoxia, edited by: Altenbach, A. V., Bernhard, J. M., and Seckbach, J., 249-285, 2012.

Koho, K. A., García, R., De Stigter, H. C., Epping, E., Koning, E., Kouwenhoven, T. J. and Van der Zwaan, G. J.: Sedimentary labile organic carbon and pore water redox control on species distribution of benthic foraminifera: A case study from Lisbon-Setúbal Canyon (southern Portugal), Prog. Oceanogr., 79, 55-82, 2008.

Koho, K. A., Nierop, K. G. J., Moodley, L., Middelburg, J. J., Pozzato, L., Soetaert, K., van der Plicht, J., and Reichart, GJ.: Microbial bioavailability regulates organic matter preservation in marine sediments, Biogeosciences, 10, 1131-1141, doi:10.5194/bg-10-1131-2013, 2013.

Kurbjeweit, F., Schmiedl, G., Schiebel, R., Hemleben, C., Pfannkuche, O., Wallmann, K., and Schäfer, P.: Distribution, biomass and diversity of benthic foraminifera in relation to sedi- ment geochemistry in the Arabian Sea, Deep-Sea Res. Pt. II, 47, 2913-2955, doi:10.1016/S0967-0645(00)00053-9, 2000.

Larkin, K. E. and Gooday, A. J.: Foraminiferal faunal responses to monsoon-driven changes in organic matter and oxygen availability at 140 and $300 \mathrm{~m}$ water depth in the NE Arabian Sea, DeepSea Res. Pt. II, 56, 403-421, doi:10.1016/j.dsr2.2008.05.037, 2009.

Larkin, K. E., Gooday, A. J., Woulds, C., Jeffreys, R. M., Schwartz, M., Cowie, G., Whitcraft, C., Levin, L., Dick, J. R., and Pond, D. W.: Uptake of algal carbon and the likely synthesis of an "essential" fatty acid by Uvigerina ex. gr. semiornata (Foraminifera) within the Pakistan margin oxygen minimum zone: evidence from fatty acid biomarker and ${ }^{13} \mathrm{C}$ tracer experiments, Biogeosciences, 11, 3729-3738, doi:10.5194/bg-11-3729-2014, 2014.

Levin, L. A.: Oxygen minimum zone benthos: adaptation and community response to hypoxia, Oceanogr. Mar. Biol., 41, 1-45, 2003.

Levin, L. A. and Gage, J. D.: Relationships between oxygen, organic matter and the diversity of bathyal macrofauna, Deep-Sea Res. Pt. II, 45, 129-163, 1998.

Levin, L. A., Huggett, C. L., and Wishner, K. F.: Control of deepsea benthic community structure by oxygen and organic-matter gradients in the eastern Pacific Ocean, J. Mar. Res., 49, 763-800, 1991.

Levin, L. A., Gage, J. D., Martin, C., and Lamont, P. A.: Macrobenthic community structure within and beneath the oxygen minimum zone, NW Arabian Sea, Deep-Sea Res. Pt. II, 47, 189-226, doi:10.1016/S0967-0645(99)00103-4, 2000.

Levin, L. A., Ekau, W., Gooday, A. J., Jorissen, F., Middelburg, J. J., Naqvi, S. W. A., Neira, C., Rabalais, N. N., and Zhang, J.: Effects of natural and human-induced hypoxia on coastal benthos, Biogeosciences, 6, 2063-2098, doi:10.5194/bg-6-2063-2009, 2009.

Levin, L. A., McGregor, A. L., Mendoza, G. F., Woulds, C., Cross, P., Witte, U., Gooday, A. J., Cowie, G., and Kitazato, H.: Macrofaunal colonization across the Indian margin oxygen minimum zone, Biogeosciences, 10, 7161-7177, doi:10.5194/bg-10-71612013, 2013.

Maas, M.: Verbreitung lebendgefärbter benthischer Foraminiferen in einer intensivierten Sauerstoffminimumzone, Indo- Pakistanischer Kontinentalrand, nödliches Arabisches Meer (Distribution of Rose Bengal stained benthic foraminifera within an intensified oxygen minimum zone, Indo-Pakistan Continental Margin, Northwest Arabian Sea), Meyniana, 52, 101-128, 2000.

Mackensen, A. and Douglas, R. G.: Down-core distribution of live and dead deep-water benthic foraminifera in box cores from the Weddell Sea and the California continental borderland, Deep-Sea Res., 36, 879-900, doi:10.1016/0198-0149(89)90034-4, 1989.

Madhupratap, M., Prasanna Kumar, S., Bhattahiri, P. M. A., Dileep Kumar, M., Raghukumar, S., Nair, K. K. C., and Ramaiah, N.: Mechanisms of the biological response to winter cooling in the northeastern Arabian Sea, Nature, 483, 549-552, 1996.

Mallon, J., Glock, N. and Schönfeld, J.: The Response of Benthic Foraminifera to Low-Oxygen Conditions of the Peruvian Oxygen Minimum Zone, in: Anoxia, edited by: Altenbach, A. V., Bernhard, J. M., and Seckbach, J., 305-321, 2012.

Milliman, J. D., Troy, P. J., Balch, W. M., Adams, A. K., Li, Y.H., and Mackenzie, F. T.: Biologically mediated dissolution of calcium carbonate above the chemical lysocline?, Deep-Sea Res. Pt. I, 46, 1653-1669, 1999. 
Moodley, L., Van der Zwaan, G. J., Herman, P. M. J., Kempers, L., and Van Breugel, P.: Differential response of benthic meiofauna to anoxia with special reference to Foraminifera (Protista: Sarcodina), Ma. Ecol.-Prog. Ser., 1997.

Mullins, H. T., Thompson, J. B., McDougall, K., and Vercoutere, T. L.: Oxygen-minimum zone edge effects: evidence from the central California coastal upwelling system, Geology, 13, 491494, 1985

Murray, J. W.: Ecology and palaeoecology of benthic foraminifera, Routledge, 1991.

Murray, J. W. and Bowser, S. S.: mortality, protoplasm decay rate, and reliability of staining technique to recognize "living" foraminifera: a review, J. Foraminif. Res., 30, 66-70, 2000.

Naidu, P. D. and Malmgren, B. A.: Do benthic foraminifer records represent a productivity index in oxygen minimum zone areas? An evaluation from the Oman Margin, Arabian Sea, Mar. Micropaleontol., 26, 49-55, doi:10.1016/0377-8398(95)000143, 1995 .

Neira, C., Sellanes, J., Levin, L. A., and Arntz, W. E.: Meiofaunal distributions on the Peru margin:: relationship to oxygen and organic matter availability, Deep-Sea Res. Pt. I, 48, 2453-2472, doi:10.1016/S0967-0637(01)00018-8, 2001.

Oliver, P. G. and Levin, L.: A new species of the family Thyasiridae (Mollusca: Bivalvia) from the oxygen minimum zone of the Pakistan Margin, J. Mar. Biol. Assoc. UK, 86, 411-416, 2006.

Paulmier, A. and Ruiz-Pino, D.: Oxygen minimum zones (OMZs) in the modern ocean, Prog. Oceanogr., 80, 113-128, doi:10.1016/j.pocean.2008.08.001, 2009.

Pawlowski, J., Holzmann, M., and Tyszka, J.: New supraordinal classification of Foraminifera: Molecules meet morphology, Mar. Micropaleontol., 100, 1-10, 2013.

Phipps, M., Jorissen, F., Pusceddu, A., Bianchelli, S., and Stigter, H. D.: Live Benthic Foraminiferal Faunas Along a Bathymetrical Transect (282-4987 M) on the Portuguese Margin (NE Atlantic), J. Foramin. Res., 42, 66-81, doi:10.2113/gsjfr.42.1.66, 2012.

Piña-Ochoa, E., Hogslund, S., Geslin, E., Cedhagen, T., Revsbech, N. P., Nielsen, L. P., Schweizer, M., Jorissen, F., Rysgaard, S., and Risgaard-Petersen, N.: Widespread occurrence of nitrate storage and denitrification among Foraminifera and Gromiida, P. Natl. Acad. Sci., 107, 11481153, doi:10.1073/pnas.0908440107, 2010.

Pozzato, L., van Oevelen, D., Moodley, L., Soetaert, K., and Middelburg, J. J.: Carbon processing at the deep-sea floor of the Arabian Sea oxygen minimum zone: A tracer approach, J. Sea Res., 78, 45-58, doi:10.1016/j.seares.2013.01.002, 2013.

Rathburn, A. E., Levin, L. A., Held, Z.. and Lohmann, K. C.: Benthic foraminifera associated with cold methane seeps on the northern California margin: ecology and stable isotopic composition, Mar. Micropaleontol., 38, 247-266, 2000.

Risgaard-Petersen, N., Langezaal, A. M., Ingvardsen, S., Schmid, M. C., Jetten, M. S. M., Op den Camp, H. J. M., Derksen, J. W. M., Piña-Ochoa, E., Eriksson, S. P., Peter Nielsen, L., Peter Revsbech, N., Cedhagen, T., and van der Zwaan, G. J.: Evidence for complete denitrification in a benthic foraminifer, Nature, 443, 93-96, doi:10.1038/nature05070, 2006.
Rixen, T., Haake, B., Ittekkot, V., Guptha, M. V. S., Nair, R. R., and Schlüssel, P.: Coupling between SW monsoon-related surface and deep ocean processes as discerned from continuous particle flux measurements and correlated satellite data, J. Geophys. Res.-Oceans, 101, 28569-28582, doi:10.1029/96JC02420, 1996.

Rixen, T., Haake, B., and Ittekkot, V.: Sedimentation in the western Arabian Sea the role of coastal and open-ocean upwelling, Deep-Sea Res. Pt. II, 47, 2155-2178, doi:10.1016/S09670645(00)00020-5, 2000.

Rogers, A. D.: The role of the oceanic oxygen minima in generating biodiversity in the deep sea, Deep-Sea Res. Pt. II, 47, 119-148, 2000.

Ryther, J. H. and Menzel, D. W.: On the production, composition, and distribution of organic matter in the Western Arabian Sea, Deep-Sea Res., 12, 199-209, 1965.

Sanders, H. L. and Hessler, R. R.: Ecology of the deep-sea benthos, Science, 163, 1419-1424, 1969.

Schumacher, S., Jorissen, F. J., Dissard, D., Larkin, K. E., and Gooday, A. J.: Live (Rose Bengal stained) and dead benthic foraminifera from the oxygen minimum zone of the Pakistan continental margin (Arabian Sea), Mar. Micropaleontol., 62, 4573, doi:10.1016/j.marmicro.2006.07.004, 2007.

Sergeeva, N. G., Gooday, A. J., Mazlumyan, S. A., Kolesnikova, E. A., Lichtschlag, A., Kosheleva, T. N., and Anikeeva, O. V.: Meiobenthos of the Oxic/Anoxic Interface in the Southwestern Region of the Black Sea: Abundance and Taxonomic Composition, in: Anoxia, edited by: Altenbach, A. V., Bernhard, J. M., and Seckbach, J., 369-401, 2012.

Stubbings, H. G.: The Marine Deposits of the Arabian Sea: An Investigation Into Their Distribution and Biology, Order of the Trustees of the British Museum, 1939.

Taylor, A. and Gooday, A. J.: Agglutinated foraminifera (superfamily Hormosinacea) across the Indian margin oxygen minimum zone (Arabian Sea), Mar. Biodiv., 44, 5-25, 2014.

Vandewiele, S., Cowie, G., Soetaert, K., and Middelburg, J. J.: Amino acid biogeochemistry and organic matter degradation state across the Pakistan margin oxygen minimum zone, DeepSea Res. Pt. II, 56, 376-392, doi:10.1016/j.dsr2.2008.05.035, 2009.

Verhallen, P. U. M.: Early development of Bulimina marginata in relation to paleoenvironmental changes in the Mediterranean, Proc. Kon. Ned. Akad. Wetensch. B, 90, 161-180, 1987.

Walton, W. R.: Techniques for recognition of living foraminifera, Contribution Cushman Foundation of Foraminiferal Research, 3, 56-60, 1952.

Ward, B. B., Glover, H. E., and Lipschultz, F.: Chemoautotrophic activity and nitrification in the oxygen minimum zone off Peru, Deep-Sea Res., 36, 1031-1051, 1989.

Wishner, K., Levin, L., Gowing, M., and Mullineaux, L.: Involvement of the oxygen minimum in benthic zonation on a deep seamount, Nature, 346, 57-59, 1990.

Wishner, K. F., Ashjian, C. J., Gelfman, C., Gowing, M. M., Kann, L., Levin, L. A., Mullineaux, L. S., and Saltzman, J.: Pelagic and benthic ecology of the lower interface of the Eastern Tropical Pacific oxygen minimum zone, Deep-Sea Res. Pt. I, 42, 93-115, 1995. 